\title{
FUNDAMENTALIZM RELIGIJNY. PRZYPADEK MORAL MAJORITY
}

„...idea rozdzielenia religii od polityki jest pomysłem szatańskim, a jeśli gdzieś jest potrzebne chrześcijaństwo, to w Waszyngtonie..."

Jerry Falwell

łowo „fundamentalizm”, zazwyczaj z niewielkim dopiskiem
„religijny”, pojawia się każdego dnia w niezliczonej ilości artykułów zamieszczanych w milionach publikacji na całym świecie. Hasło to drażni, alarmuje, skupia uwage czytelnika - brzmi obco i wywołuje niepokój. Jest niczym sygnał, a nawet synonim tego, co może każdemu z nas w dzisiejszym ponowoczesnym świecie zagrażać najbardziej. W takiej sytuacji łatwo o nadużycia. Niejednokrotnie pojęcia nieustannie obecne w mediach tracą swe właściwe znaczenia, które zastapione są zbudowana wokół nich bardziej lub mniej sensacyjną ideologia. Trudno oprzeć się wrażeniu, iż pojęcie „fundamentalizmu religijnego" znalazło się obecnie w zbliżonych okolicznościach. Lektura prasy codziennej dostarcza wielu przykładów nadużyć językowych, z których część popełniona została zapewne nieświadomie. „Fundamentalizm religijny” stał się dzisiaj hasłem nieostrym, nieprecyzyjnym, niezdefiniowanym a tym samym niezwykle pojemnym. „Fundamentalizmem religijnym” określa się tak wiele zjawisk, iż warto zastanowić się nad tym, kiedy określenie to jest prawomocne a kiedy nie. Nie negując istnienia samego fenomenu, w mojej pracy podejmę próbę zdefiniowania oraz zbadania problemu. Będzie to próba pokazania nie tylko, iż nie jest to abstrakcyjne pojęcie, lecz namacalna sytuacja społeczna i, co więcej, iż możliwe jest przeprowadzenie jego analizy i usystematyzowania. 


\section{Próba definicji kluczowego pojęcia}

Fundamentalizm religijny jest hasłem kluczowym nie tylko w mediach, jest także przedmiotem badań wielu naukowców i badaczy współczesnego życia społecznego. W pracach naukowych pojawiają się tysiące prób zdefiniowania badanego przedmiotu. Jest to jednak zadanie niełatwe, nie tylko $\mathrm{z}$ powodu skomplikowania samego fenomenu. Problemem jest także pejoratywne nacechowanie pojęcia, które towarzyszy mu od połowy lat 70., kiedy to wielu amerykańskich badaczy zaczęło postrzegać wszelkie rodzaje fundamentalizmów jako jedne $\mathrm{z}$ największych zagrożeń ładu społecznego. Sytuacja pogorszyła się oczywiście po 11 września 2001 roku.

Rodowód pojęcia nie jest dla badaczy zjawiska tajemnicą: fundamentalizm był bowiem pod koniec XIX wieku próbą autodefinicji anglosaskiego protestantyzmu na terenach USA. Współczesne próby definicji podejmowane są m.in. przez negacje: stwierdza się, iż fundamentalizm religijny nie jest erupcją archaicznych pokładów religijności czy też reliktowym residuum mentalności tzw. przednowoczesnej ani tym bardziej ruchem konserwacji ${ }^{1}$. Często określa się także fundamentalizm religijny jako swoisty ruch odnowy, który jest „antylaicki, antyuniwersalistyczny i, z wyjątkiem chrześcijańskich, antyzachodni" 2. Definicja encyklopedyczna proponowana przez Marię Marczewska-Rytko podaje, iz fundamentalizm to ,jedna z najważniejszych postaw intelektualnych i ideologicznych współczesnego świata"3. Na tle wielu prób objaśnienia zjawiska często określanego jako forma ruchu społecznego lub sekta, w ramach szerszej wspólnoty aksjologicznej, ciekawe i charakterystyczne, zwłaszcza dla politologa, jest nowatorskie podejście profesora Bassama Tibi'ego. Wielokrotnie w swych pracach podkreślał on nie tylko, iż fundamentalizm jest zjawiskiem globalnym (należy mówić raczej o wielu fundamentalizmach niż o jednym) kojarzonym zazwyczaj z islamem, lecz także to, że fundamentalizm jest ideologia polityczna. Według definicji, która pojawia się w pracy pt. Fundamentalizm religijny, jest kilka cech, które świadczą o tym, iż badane zjawisko jest w większym stopniu ideologią polityczną niż

${ }^{1}$ D. Motak, Nowoczesność i fundamentalizm. Ruchy antymodernistyczne w chrześcijaństwie, dz. cyt., s. 14.

2 J. Malinga, Globalizacja. Między ragubiona a odzyskana tożsamościa, w: Oblicza procesón globalizacji, pod. red. Marka Pietrasia, Wydawnictwo Uniwersytetu Marii CurieSkłodowskiej, Lublin 2002, s. 214.

${ }^{3}$ Encyklopedia politologii, Wydawnictwo Zakamycze, t. 1, Kraków 1999, s. 105. 
fenomenem czysto religijnym. Najbardziej istotna $z$ tych cech jest propozycja alternatywnego światopoglądu, z którą wychodzi fundamentalizm, a która to ma być odpowiedzią na podwójny kryzys: kryzys wartości oraz kryzys strukturalny ${ }^{4}$.

Dla potrzeb tej pracy postanowiłam przyjąć definicję zwięzłą i synkretyczną. Przez pojęcie fundamentalizmu religijnego rozumieć będę wszelkie religijne ruch protestu i opozycji wobec kulturowych podstaw przebiegających współcześnie procesów modernizacji. Istotnym jest także, że ruchy te są krytyczne nie tylko wobec nowoczesnych prądów teologicznych, ale i wobec transformacji instytucji religijnych. Cechą ich jest zorientowanie na obronę lub przywrócenie tradycyjnych dogmatów i form wiary.

\section{Struktura pracy oraz wykorzystane źródła}

Kwestia zdefiniowania problemu jest jedynie punktem wyjściowym mej pracy. W dalszej jej części postaram się dokładniej omówić zjawisko fundamentalizmu religijnego, opisując jego cechy oraz przedstawiając możliwe koncepcje przyczyn jego powstania i wzrastającej popularności. Integralną częścią tej pracy są dwa zagadnienia, które są w moim przekonaniu istotne dla zrozumienia omawianego problemu. Pierwszym z nich jest neofundamentalizm, a drugim rozróżnienie między dwoma pojęciami: tradycjonalizmem a fundamentalizmem. Dodatkiem oraz ilustracja tez zawartych w eseju jest krótka prezentacja jednego z najbardziej interesujących ruchów fundamentalistycznych, działającego w latach 80. XX wieku na terenie USA - Moral Majority. Przygotowując tę pracę korzystałam $z$ wielu publikacji zarówno zagranicznych jak i rodzimych autorów. Nie sposób pominąć autorytetów zmagających się z tematem od lat, ale warto zauważyć także prace młodych naukowców, które powstały z okazji coraz częściej organizowanych konferencji naukowych poświęconych zagadnieniom globalizacji.

\section{Cechy fundamentalizmu religijnego}

Definicja jest zawsze tylko jedną z możliwych prób zrozumienia danego zjawiska, niezwykle pomocna okazać może się także jego charakterystyka. Możliwe jest w przypadku fundamentalizmu religijnego wyodrębnienie pewnych cech, stanowiących o jego istocie. Jest to zestaw w pewien sposób uniwersalnych wyznaczników, opisujących każdy

${ }^{4}$ B. Tibi, Fundamentalizm religijny, PIW, Warszawa 1997, s. 34. 
fundamentalizm religijny, zarówno hinduski, islamski jak i protestancki. Próbę ich usystematyzowania podjął Gabriel Almond wraz ze swymi współpracownikami: Emanuelem Sivan'em i Scottem Appleby.

Za pierwszorzędną cechę każdego fundamentalizmu uznali oni jego reaktywność i obronność. Fundamentalizm jest reakcją obronna spowodowana poczuciem zagrożenia własnej tożsamości kulturowej. W tym sensie postrzegać można go jako ruch oporu wobec utraty własnej tożsamości, który w rezultacie staje się ruchem autoafirmatywnym. W wyniku procesów modernizacji podważone zostały religijne podstawy legitymacji, a co za tym idzie zniszczone zostały dawne koncepcje rzeczywistości. Jak pisze Benjamin Barber: „rozwój ekonomiczny powoduje mnożenie się nowych doczesnych potrzeb i obsesję ich zaspokajania, a sztuka i nauka zagrażaja prostocie i naturalnej wierze zwykłych kobiet i mężczyzn" ". Oczywiście wywołało to reakcję przeciwną kulturowym i psychospołecznym skutkom modernizacji.

Kolejną istotna cechą jest selektywność, przejawiająca się w trzech aspektach: selektywnej obronie własnej tradycji religijnej, selektywnym przyswajaniu danych elementów nowoczesności oraz selektywnej akceptacji pewnych konsekwencji nowoczesności. $\mathrm{Na}$ równi z tym, fundamentalizm cechuje tzw. moralny manicheizm, absolutny dualizm w postrzeganiu świata, bezdyskusyjny jego podział na część dobrą i zła. Doskonałym odzwierciedleniem tej cechy jest obraz wroga pojawiający się w ruchach fundamentalistycznych. Obejmuje on zazwyczaj jednostki należące do niedostatecznie ortodoksyjnego lub skorumpowanego establishmentu, świeckie państwo jako ideę lub świeckie społeczeństwo jako takie. Pokrewna tej cechy jest typowy absolutyzm oraz nieomylność przypisywane tzw. świętej księdze danej religii. Koran, Talmud czy Biblia postrzegane sa jako dosłowne, ostateczne i jedyne źródło prawdy. Podejście to sprzyja rozwijaniu wszelkiego typu teorii i wierzeń millenarystycznych czy mesjanistycznych, włącznie z przekonaniem o wiecznej szczęśliwości wybranych oraz nieustającym potępieniu reszty. Ciekawą i charakterystyczną jest także wewnętrzna organizacja komórki fundamentalistycznej, zakładająca uprzywilejowane członkostwo, ostre zarysowanie granic grupy wraz z wysokim stopniem lojalności i przywiązania do niej. Osobną kwestią jest autorytarna struktura wewnętrzna, pomimo teoretycznie dobrowolnego i równego

\footnotetext{
5 A. Mrozek-Dumanowska, W spótczesny ruch odnowy islamu. W poszukiwaniu własnej to:̇samości kulturowej, Prace Monograficzne Zakładu Krajów Pozaeuropejskich Polskiej Akademii Nauk, Warszawa 2000, s. 19.

${ }^{6}$ B. Barber, Dìihad kontra Mc Świat, Warszawskie Wydawnictwo Literackie Muza S.A., Warszawa 1997, s. 268.
} 
członkostwa, skupiona zazwyczaj wokół charyzmatycznego lidera oraz ostra regulacja zachowania według określonych reguł.

\section{Źródła fundamentalizmów}

Dla lepszego zrozumienia zjawiska fundamentalizmu wielu naukowców rozpoczęło badania mające na celu odkrycie i wytłumaczenie przyczyn jego powstawania. Badania te miały w zamierzeniu także wymiar praktyczny, związany z rosnącym zagrożeniem społecznym, jakie ruchy fundamentalistyczne moga stanowić. Najbardziej podstawową i najczęściej przywoływaną teorią upatrująca źródeł fundamentalizmu jest hipoteza, którą określić można mianem ekonomicznej. Wiąże ona powstanie fenomenu ze zjawiskiem marginalizacji społecznej i wykluczenia. Już Zygmunt Bauman zauważył, że postępująca segregacja przestrzenna, separacja oraz wykluczenie sa immanentną częścia procesu globalizacji ${ }^{7}$. Wg hipotezy ekonomicznej czynnikiem sprzyjającym jest nieskuteczność działań światowego systemu gospodarczego w kierunku zmniejszania dysproporcji w podziale dóbr ${ }^{8}$. Teoria ta wydaje się być oczywista, jednak istnieja co do jej prawdziwości pewne zastrzeżenia, polegające przede wszystkim na fakcie, iż ruchy fundamentalistyczne w rzeczywistości rzadko nastawione są na postulowanie zmian ekonomicznych, a podejście to bliższe jest grupom populistycznym.

Inną teoria jest hipoteza, którą określić można mianem kulturowo-cywilizacyjnej. Wyjaśnia ona rodzenie się ruchów o charakterze fundamentalistycznym zwłaszcza poza zachodnim kręgiem cywilizacyjnym. Hipoteza głosi, iż grupy takie powstaja w celu zlikwidowania kompleksu niższości wobec cywilizacji zachodniej. Są więc szeroko pojęta próbą odzyskania poczucia własnej wartości i tożsamości, a co za tym idzie także godności. W tym przypadku tzw. powrót do źródeł lokalnej tradycji i religii tożsamy jest z aktem ochrony własnej cywilizacji. Podobnie wyłanianie się tendencji fundamentalistycznych tłumaczy hipoteza modernizacyjna. W tym wypadku procesy globalizacyjne, poprzez ciagła zmienność, wytworzyły permanentny brak poczucia bezpieczeństwa. Ten z kolei wytworzył silną potrzebę uczynienia rzeczywistości przewidywalną, zrozumiałą i znana, potrzebę, która zaspokojona być może właśnie przez tzw. powrót do źródeł.

7 Z. Bauman, Globalizacja. I co z.tego dla ludzi wynika?, PIW, Warszawa 2000, s. 7.

8 A. Mrozek-Dumanowska, Konstruk.cja światów symbolicznych jako alternatywa globalizacji, w:

Globalizacja i to $\dot{s} s a m o s ́ c ́$, pod. red. Jerzego Zdanowskiego, Wydawnictwo Naukowe

Askon, Warszawa 2003, s. 112. 
Inspirująca jest próba wyjaśnienia zjawiska przedstawiona przez profesora Wnuka-Lipińskiego, który stworzył tzw. hipotezę socjopsychologiczna. U jej podstaw leży założenie, iż proces globalizacji niesie ze soba trzy procesy, które w istotny sposób zmieniają otoczenie społeczne człowieka. Pierwszy z tych procesów to fragmentacja. Mamy z nią do czynienia, gdy w lokalnym otoczeniu pojawia się wielość nowych, ponadlokalnych odniesień ${ }^{9}$. Kolejny nazwać można relatywizacją następuje, gdy normy, wartości czy sposoby życia dotychczas kultywowane przestaja mieć charakter absolutny i stają się tylko jedną z wielu możliwych form bytowania. Trzeci z kolei - detradycjonalizacja jest zupełnie jasny. Wszystkie te procesy burzą ukształtowany wcześniej porządek, w miejsce spokoju i ładu wprowadzając chwiejność, chaos i nieobliczalność. Szybko moga doprowadzić do pełnego kryzysu tożsamości, któremu towarzyszy lęk, poczucie pustki i utrata sensu, które w doskonały sposób wypełnić moga ruchy o charakterze fundamentalistycznym. Istotnym dla tej hipotezy jest pojęcie konwersji fundamentalistycznej, będące gotowościa do zaakceptowania nowej spójnej perspektywy aksjologicznej, która przywróciłaby sens istnieniu w środowisku społecznym ${ }^{10}$. Warto zaznaczyć, iż konwersja nie oznacza wcale nagłej iluminacji. Wręcz przeciwnie - jest stopniowym procesem wchodzenia w nową rolę, w nowy zestaw wierzeń, który następuje w czasie interakcji z osobami i grupami przeżywającymi podobne problemy. Hipoteza ta wydaje się najtrudniejsza do obalenia, niezwykle trudno znaleźć wyjątek, którego powstania nie wyjaśniałaby. Jest to z pewnością najpełniejsza teoria dotycząca nie tylko przyczyn powstania, ale i powodów popularności współczesnych ruchów fundamentalistycznych.

\section{Neofundamentalizm}

Mówiąc o współczesnych ruchach fundamentalizmu religijnego natknąc można się na pojęcie neofundamentalizmu. Niektórzy z badaczy, zajmujący się obserwacją procesów globalizacji i modernizacji doszli do wniosku, iż mimo że nie jest to zjawisko nowe, dzisiaj nabrało już tak wielu niespotykanych dotychczas cech, że zachodzi potrzeba używania innego pojęcia - neofundamentalizm w miejsce fundamentalizmu. Jednym z nich jest Olivier Roy, który w swym eseju przedstawia ewolucję

\footnotetext{
9 Z. Wnuk-Lipiński, Świat międyepoki. Globalizacja. Demokracja. Państwo Narodowe, Wydawnictwo Znak, Kraków 2004, s. 294.

10 Tamże, s. 293.
} 
ruchów fundamentalistycznych $\mathrm{z}$ ponadnarodowych interesów w stronę nacjonalizmów, jego zdaniem tak istotna, iż domaga się ona ukucia nowego, bardziej aktualnego pojęcia ${ }^{11}$. Cechy charakteryzujące nowy fundamentalizm to przede wszystkim jego dążenie do zaistnienia jako aktor na lokalnych scenach politycznych oraz ewolucja ideologii w stronę coraz większego konserwatyzmu i radykalizmu. Istotne jest coraz większe upolitycznienie religii połączone z jej nacjonalizacją. Kluczowa jest tutaj aktywizacja biernych dotychczas warstw społeczeństwa w kraju oraz coraz mniejsze poparcie dla ruchu poza jego granicami. Alarmująca jest także inna tendencja: coraz częstsze nastawienie antychrześcijańskie, kwestia zupełnie nieistniejąca jeszcze dekadę temu. Podobnie jak nacisk na purytanizm oraz coraz częstszy profil osobowy fundamentalisty jako człowieka wykształconego w jednym z krajów cywilizacji zachodniej, beznarodowca. Wszystko to świadczy o tym, że rzeczywiście mamy obecnie do czynienia z nowa formą fundamentalizmu religijnego, która powstała jako skutek procesów globalizacji i modernizacji, i wobec której należy używać adekwatnego pojęcia neofundamentalizmu.

\section{Tradycjonalizm a fundamentalizm}

Problemy językowe w dyskusji na temat fundamentalizmu pojawiaja się nie tylko w momencie konieczności zdefiniowania samego zjawiska, czy zmierzenia się z hasłem neofundamentalizmu, lecz także, gdy pada słowo „tradycjonalizm”. Warto więc wyszczególnić kilka najistotniejszych różnic między fundamentalistą a tradycjonalistą. Ten pierwszy żyje w przekonaniu, iż złoty wiek doskonałości dopiero nadejdzie, gdy wszyscy poznaja prawdę absolutną, której to właśnie on jest depozytariuszem. Inaczej tradycjonalista: dla niego złoty wiek minął bezpowrotnie, żyje w świece zdegenerowanym, gorszym, zagubionym. Trudno dopatrzyć się w tradycjonalistycznym podejściu do świata jego manichejskiego postrzegania lub absolutyzmu w kwestii istnienia prawdy. Inne są także cele działania osób o tych dwóch postawach. Tradycjonalista bowiem zawsze dąży do obrony pewnych cennych elementów spuścizny w celu przekazania jej kolejnym pokoleniom, podczas gdy fundamentalista dąży do zniszczenia zła, aby przyśpieszyć triumf swej prawdy absolutnej. I co najistotniejsze, o ile można wyobrazić sobie z łatwością pasywnego tradycjonalistę, o tyle istnienie pasywnego fundamentalisty jest niemożliwe. Fundamentalizm nie

${ }^{11} \mathrm{http}: /$ www.ssrc.org/sept11/essays/roy.htm 
pozostawia miejsca na obojętność czy bierność, na tolerowanie zdefiniowanego zła. Już po tych kilku stwierdzeniach oczywista staje się olbrzymia różnica znaczeniowa między tymi dwoma pojęciami, które nie powinny być używane zamiennie.

\section{Studium przypadku: Moral Majority}

Dla potwierdzenia tez zawartych w tej pracy, chciałabym przedstawić jeden $\mathrm{z}$ ruchów funkcjonujacych w latach 80. na terenie USA, a który z pewnością nazwany może być fundamentalistycznym. Już pod koniec lat 70. odnotowano tam wzrost liczebności konserwatywnych grup protestanckich. Tłumaczono go jako reakcję na rozczarowanie epoka kryzysu, wojną w Wietnamie, kryzysem paliwowym, aferą Watergate i wreszcie przemianami społecznymi lat 60. Powrót do konserwatywnych przekonań potwierdził okres prezydentury Ronalda Reagana, oraz dominacja ugrupowań o ideologii konserwatywnej na ówczesnej scenie politycznej: Nowej Prawicy Religijnej oraz Nowej Prawicy Chrześcijańskiej ${ }^{12}$. Wokół partii tych skupione były zastępy mniejszych organizacji, niejednokrotnie o charakterze fundamentalistycznym, populistycznym a nawet faszyzującym. Najistotniejszą z nich była założona w 1979 roku przez słynnego teleewangelistę Jerry'ego Falwella wraz z grupa pomniejszych konserwatywnych polityków, największa z tych organizacji nazwana Moral Majority. Według własnych szacunków zrzeszała ona 110 tysięcy aktywnych członków, a cieszyła się poparciem ponad $7 \mathrm{mln}$ Amerykanów ${ }^{13}$.

Założyciel oraz lider Moral Majority wymieniał cztery naczelne cechy światopoglądowe ruchu, wśród których naczelne miejsce zajmowało poparcie dla życia ludzkiego, co w praktyce oznaczało walkę o delegalizację aborcji. Kolejną cechą było poparcie dla tradycyjnego modelu rodziny, praktycznie sprowadzające się do walki przeciwko prawom par homoseksualnych do zawierania związków zalegalizowanych. Kolejno, jednymi z głównych wyznaczników były też: poparcie dla tradycyjnie pojmowanej moralności oraz proamerykańskie nastawienie.

Praktyczne działania Moral Majority sprowadzały się do aktywności na kilku polach: edukacji, lobbingu oraz polityki. Organizacja

\footnotetext{
${ }^{12}$ D. Motak, Nowoczesność i fundamentaližm. Ruchy antymodernistyczne w chrześsisjaństwie, dz. cyt., s. 85.

13 Tamże, s. 87.
} 
pod wodzą Falwella organizowała sieć własnych ośrodków szkolnych, szkoleniowych i wykładowych. Związki z polityką były niezwykle silne, organizacja często zwracała uwagę opinii publicznej na głosowania w Senacie, mobilizowała zbieranie list wyborców konserwatywnych oraz przede wszystkim lobbowała na rzecz interesujących ją kwestii: aborcji, edukacji zgodnej z Bibliq, patriarchalnego modelu rodziny, czy wzmocnienia sił militarnych USA. Moral Majority obok niezwykle liberalnego podejścia w dziedzinie ekonomii, gdzie składali hołd niemalże ultrakonserwatywnej ekonomii Miltona Friedmana, cechowała się skrajnym antykomunizmem i nacjonalizmem. To wtedy bowiem, ukuła się doktryna atomowa a ZSRR nazywano „Imperium Zła” bądź „Antychrystem”.

Analiza struktury organizacyjnej i członkowskiej ruchu ukazuje, iż składał się on głównie z białych protestantów, pochodzących z mniej wykształconych warstw społecznych. Popularność Moral Majority aż do końca lat 80. przypisuje się niezwykle umiejętnemu połączeniu tematów związanych z fundamentalistycznym powrotem do ,źródeł wiary” z ówczesną sytuacją społeczną i polityczną zarówno wewnętrzną jak i międzynarodową.

\section{Podsumowanie}

Problem fundamentalizmu, jego przyczyn, charakterystyki oraz różnorodności jest kwestią niezwykle obszerną, zarazem szalenie aktualną. Jest to materia, która musi być współcześnie badana i dyskutowana, ponieważ stanowi integralny element otaczającej nas rzeczywistości. Jest już namacalnym zjawiskiem, które może zaistnieć w życiu każdego z nas. Warto więc zastanawiać się nad jak najprawdziwszym i najlepszym sposobem rozprawiania się $z$ tym tematem. W mojej pracy próbowałam ukazać jak wiele kwestii jest niejasnych, zwłaszcza w sferze posługiwania się pojęciami nieostrymi lub niezdefiniowanymi. Próbowałam zdefiniować pojęcia, które wydawały mi się kluczowe a zarazem najbardziej problematyczne. Problem globalizacji, modernizacji oraz wiążącego się z tymi procesami wzrostu znaczenia fundamentalizmów religijnych na świecie stanowi szerokie pole do popisu dla obserwatorów życia społecznego. Wiele procesów zostaje na razie niezrozumianych i nieopisanych. Stanowić to powinno impuls do badań nad tą żywą przecież materią. 